\title{
ОСВІТА ТА ЕКОНОМІЧНА ВИЗНАЧЕНІСТЬ: ЗВ'ЯЗОК ЯВИЩ ТА ОСОБЛИВОСТІ РЕАЛІЗАЦІЇ ЩОДО РИНКУ НЕРУХОМОСТІ
}

\author{
Усик Віра Іванівна, \\ доктор економічних наук, професор кафедри, \\ ДВНЗ «Київський начіональний університет імені Вадима Гетьмана», \\ ORCID: https://orcid.org/0000-0002-0938-400X, \\ Дзюбко Віктор Васильович, \\ старший викладач кафедри теоретичної та прикладної економіки, \\ ВНЗ «Університет економіки та права «КРОК», \\ ORCID: https://orcid.org/0000-0003-0759-457X
}

Анотація. Розділ присвячено аналізу зв'язку між освітою та економічною визначеністю. Досліджено передавальні ланки в реалізації цього зв'язку. Окреслено вимоги до змісту і форм освіти з огляду на потреби сталого розвитку, нагромадження людського капіталу та реалізації результативної освітньої політики. Акцентовано увагу на підготовці фахівців для українського ринку нерухомості. Окреслено ті проблеми професіоналізації освіти для ринку нерухомості, вирішення яких сприятиме стабілізації ситуації власне на цьому ринку та в національній економіці загалом.

Ключові слова: освіта як фактор економічної визначеності, освітня політика, людський капітал, сталий розвиток, професіоналізація освіти, професіональна освіта для ринку нерухомості.

Актуальність дослідження впливу освіти на досягнення вищого рівня економічної визначеності пояснюється насамперед значним стабілізуючим потенціалом освіти. Факт існування такого потенціалу доведено багатьма економетричними дослідженнями та подіями історії багатьох країн. За обмежених можливостей і ресурсів розвитку економіки й суспільства освіта неодноразово ставала вирішальним чинником стабілізації. Важливо, що в якості чинника стабілізації освіта постає не автоматично. Діє певний передавальний механізм впливу освіти на економічну визначеність. На наш погляд, цей механізм має бути предметом спеціальних досліджень. Прикладне значення таких досліджень - це обгрунтування способів та форм модернізації освіти 3 урахуванням потреб вищого рівня економічної стабільності й визначеності.

В основу цього дослідження покладено гіпотезу про те, що зміст освіти, форми, в яких вона здійснюється, можуть створювати підгрунтя для вищого рівня економічної стабільності. 
Зв'язок між освітою та економічною визначеністю не $\epsilon$ безпосереднім. Він опосередкований певними ланками (елементами) особливого передавального механізму. Лише за певних умов ці ланки передаватимуть імпульси, отримані від освіти, у бік більшої економічної визначеності. За інших умов освіта може ставати чинником невизначеності. Ідею про передавальні елементи і логіку зв'язку між освітою та економічною визначеністю подано на рис. 1.

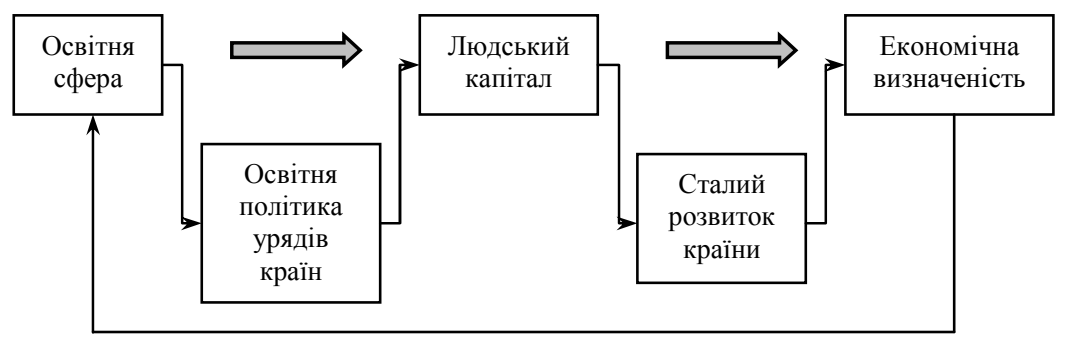

Рис. 1. Зв'язок освіти та економічної визначеності

Джерело: створено авторами самостійно.

3 використанням рис. 1 візуалізовано ідею про те, що освіта впливає на рівень економічної визначеності, передусім через людський капітал. Твердження про формування людського капіталу під впливом освіти $є$ традиційним, поширеним і незаперечним. Багато разів були перевірені й факти про вплив освіти через людський капітал на економічне зростання. Новизна ж запропонованого підходу, ілюстрованого на рис. 1, пов'язана 3 двома додатковими ідеями, а саме:

- про те, що зв'язок між освітою та формуванням i нагромадженням людського капіталу опосередковується політикою урядів, яку вони реалізують в освітній сфері (освітньою політикою);

- про те, що людський капітал забезпечує економічну визначеність тоді, коли використовується суспільством як ресурс сталого розвитку.

Для того щоб дійти висновку про освітню систему, здатну забезпечувати вищий рівень економічної визначеності, необхідно спиратися на уявлення про зміст економічної визначеності/невизначеності [1]. Для нашого дослідження важливими $є$ принаймні такі характеристики (ознаки) економічної визначеності:

- економічна визначеність пов'язана 3 волатильністю, тобто 3 відхиленнями економічних параметрів від певних рівноважних значень таких економічних змінних, як темпи економічного зростання, рівень зайнятості ресурсів, рівень цін тощо;

- економічна визначеність $є$ похідною від характеру очікувань економічних суб'єктів, відтак, вона суттєво залежить від інформованості 
й освіченості громадян, від довіри до публічної влади, до окремих спільнот тощо;

- економічна визначеність забезпечується інституиіоналізацією, тобто унормованістю економічних процесів, дотриманням цих норм, а також відповідністю створених норм об'єктивним потребам суспільства, яке розвивається.

Якщо вищий рівень економічної визначеності залежить від освіти, логічно обгрунтовувати пріоритети змін в освіті саме з потреб досягнення такої визначеності.

За логікою зв'язків, репрезентованих на рис. 1, економічна визначеність, сформована під впливом освіти, досягається тоді, коли розвиток країни набуває ознак сталого розвитку.

Як відомо, термін «сталий розвиток» $є$ офіційним українським відповідником англійського терміна «sustainable development». Останній, 3 огляду на контекст, може тлумачитися як «життєздатний розвиток», «внутрішньо підтримуваний розвиток», «збалансований розвиток» тощо.

За визначенням Комісії ООН зі сталого розвитку, мета останнього - це задоволення потреб сучасних поколінь без створення загроз для майбутніх поколінь задовольняти майбутні потреби. Теорія сталого розвитку є альтернативою до теорії економічного зростання на засадах екстенсивної моделі. Остання, зокрема, не акцентує увагу на екологічній небезпеці, вичерпності невідтворюваних природних ресурсів, які забезпечують економічне зростання. Поняття «сталий розвиток» та «стале зростання» використовуються як близькі за змістом.

Власне концепція сталого розвитку дозволила подивитися на економічне зростання, крім іншого, й під кутом зору економічної невизначеності. Зокрема, це відбулося й тому, що сталий розвиток пояснюється як той, що врівноважує економічні, соціальні та екологічні аспекти життя суспільства [2]. А в якості умов стійкого економічного зростання розглядаються гідні умови праці для всього населення працездатного віку, доступність фінансових активів, розвинена банківська та виробнича інфраструктура тощо [3].

Дотичними до проблем економіки невизначеності є актуальні ознаки економічного зростання, визначені у пріоритетах стратегії СС «Europe 2020». У документі йдеться про розумне зростання (за більш ефективних інвестицій в освіту, дослідження та інновації), про стале зростання (при низьковуглецевій економіці), про інклюзивне зростання (при створенні нових робочих місць та подоланні бідності) [4]. Ще більш важливі для нашого дослідження ідеї містить документ «Порядок денний сталого розвитку до 2030 року». У ньому сформульовано мету сталого розвитку, пов'язану з освітою, а саме: «...забезпечити всіх, хто навчається, знаннями та навичками, які необхідні для сприяння сталому розвитку...» [5]. 
Загалом, концепція сталого розвитку передбачає досягнення 17 цілей, кожна 3 яких у певний спосіб пов'язана з людським капіталом. Тому, за поширеним у науці уявленням, реалізація сталого розвитку забезпечується нагромадженням людського капіталу. Доведено, що ті країни, які інвестують у людський капітал, можуть суттєво підвищити свою конкурентоспроможність, особливо в умовах швидких змін. Тому адаптація економіки та суспільства до цих змін, отже, й вищий рівень визначеності, забезпечується нагромадженням людського капіталу.

Попри деякі відмінності у підходах до визначення поняття «людський капітал», у науці вже зафіксовано те, що є доведеним фактом:

- людський капітал створюється на основі «формального навчання, освіти та практичного досвіду» [6], він, як і будь-який інший капітал, передбачає інвестиції, передусім інвестиції в освіту;

- вищий рівень знань та навичок створює переваги i для окремих носіїв людського капіталу (кожний додатковий рік навчання помітно збільшує дохід людини [7; 8]), і для національної економіки загалом. Зокрема, перевищення певною країною на 1 в.п. середнього світового показника рівня людського капіталу корелює 32,5 в.п. відносного зростання продуктивності праці та 3 1,5 в.п. зростання валового національного доходу на одну особу.

- інвестиції в людський капітал - це фінансування в здоров'я, освіту та культуру, яке сприяє кращій адаптації до нових умов у швидко змінюваному світі [9], а відтак, ці інвестиції сприяють і більшій інклюзивності - включеності громадян у життя окремих спільнот та суспільства [10].

Зв'язок між власне освітою та людським капіталом, за нашою логікою, опосередковується освітньою політикою. Як і будь-яка інша, освітня політика охоплює цุiлi, що віддзеркалюють суспільні цінності та пріоритети. Освітня політика передбачає використання інструментів досягнення цілей і певні інститути, які забезпечують поєднання цілей та інструментів. Українські дослідники освітньої політики зазвичай акцентують увагу саме на цілях освітньої політики [11; 12]. Ймовірно, що таке акцентування пояснюється тим, що українська влада не демонструє глибокого розуміння правдивих актуальних цілей освітньої політики.

Для досягнення визначених цілей освітня політика має спиратися на певні правила - усвідомлені та інституційно забезпечені вимоги до діяльності. Правила стосуються як власне порядку надання освітніх послуг закладами освіти, так і державного фінансування освіти. Правила політики загалом та освітньої політики зокрема $\epsilon$, на наш погляд, необхідною умовою вищого рівня економічної визначеності. 
Оцінювання впливів політики, що здійснюється, на макроекономічну стабільність при порівнянні двох груп країн - 3 реалізованими та нереалізованими фінансовими правилами - дало важливі результати. Це висновок про те, що в країнах 3 традицією застосування правил зазвичай досягається вищий рівень економічної стабільності.

Освітня політика уряду, яка насамперед виявляється у рівні та способах фінансування освіти, стає предметом багатьох міжнародних досліджень. Зокрема, у звіті Свропейської асоціації університетів за 2020 р. виокремлено п'ять груп країн саме за критерієм зв'язку між фінансуванням освіти та економічним зростанням [13] (аналітична табл. 1).

Таблиця 1

Зв'язок показників фінансування освіти та темпів економічного зростання

\begin{tabular}{|l|l|l|}
\hline \multicolumn{1}{|c|}{ Показник } & \multicolumn{1}{|c|}{ Опис } & \multicolumn{1}{|c|}{ Країна } \\
\hline $\begin{array}{l}\text { Фінансування } \\
\text { освіти } \uparrow>\text { ВВП } \uparrow\end{array}$ & $\begin{array}{l}\text { Темпи фінансування освіти } \\
\text { вищі темпів економічного } \\
\text { зростання }\end{array}$ & $\begin{array}{l}\text { Австрія, Німеччина, Ісландія, } \\
\text { Люксембург, Хорватія, Данія, } \\
\text { Швеція, Швейцарія, Норвегія, } \\
\text { Португалія, Нідерланди, } \\
\text { Туреччина }\end{array}$ \\
\hline $\begin{array}{l}\text { Фінансування } \\
\text { освіти } \uparrow<\text { ВВП } \uparrow\end{array}$ & $\begin{array}{l}\text { Темпи фінансування освіти } \\
\text { нижчі темпів економічнго } \\
\text { зростання }\end{array}$ & $\begin{array}{l}\text { Франція, Польща, Угорщина, } \\
\text { Словенія, }\end{array}$ \\
\hline $\begin{array}{l}\text { Фінансування } \\
\text { освіти } \downarrow / \text { ВВП } \uparrow\end{array}$ & $\begin{array}{l}\text { Темпи фінансування освіти } \\
\text { знижуються, незважаючи } \\
\text { на економічне зростання }\end{array}$ & $\begin{array}{l}\text { Чсхія, Словаччия, Фінляндія, Естонандія, } \\
\text { Литва, Сербія, Румунія }\end{array}$ \\
\hline $\begin{array}{l}\text { Фінансування } \\
\text { освіти } \downarrow>\text { ВВП } \downarrow\end{array}$ & $\begin{array}{l}\text { Темпи фінансування освіти } \\
\text { знижуються швидше, ніж } \\
\text { відбувається економічний } \\
\text { спад }\end{array}$ & \\
\hline
\end{tabular}

Джерело: розроблено на основі [14].

Як свідчить інформація, подана в таблиці, три (перша, друга, четверта) групи країн демонстрували прямий зв'язок між витратами на вищу освіту та темпами економічного зростання. Тобто, у цих трьох групах країн зростання ВВП збільшувалося на тлі збільшення інвестицій в освіту і навпаки. Ці три групи охоплювали приблизно 65\% загальної кількості досліджуваних країн. Натомість, третя група демонструвала обернений зв'язок. Такі країни становлять приблизно 35\% кількості аналізованих країн.

Освітня політика урядів країн визначається не лише досягнутим економічним потенціалом, відповідно, можливостями державного фінансування освіти, а й демографічною ситуацією. До прикладу, в 
дослідженні Свропейської асоціації університетів репрезентовано різні моделі освіти, сформовані під впливом двох згаданих чинників фінансового та демографічного - у період 2008 - 2017 pp. (рис. 2).

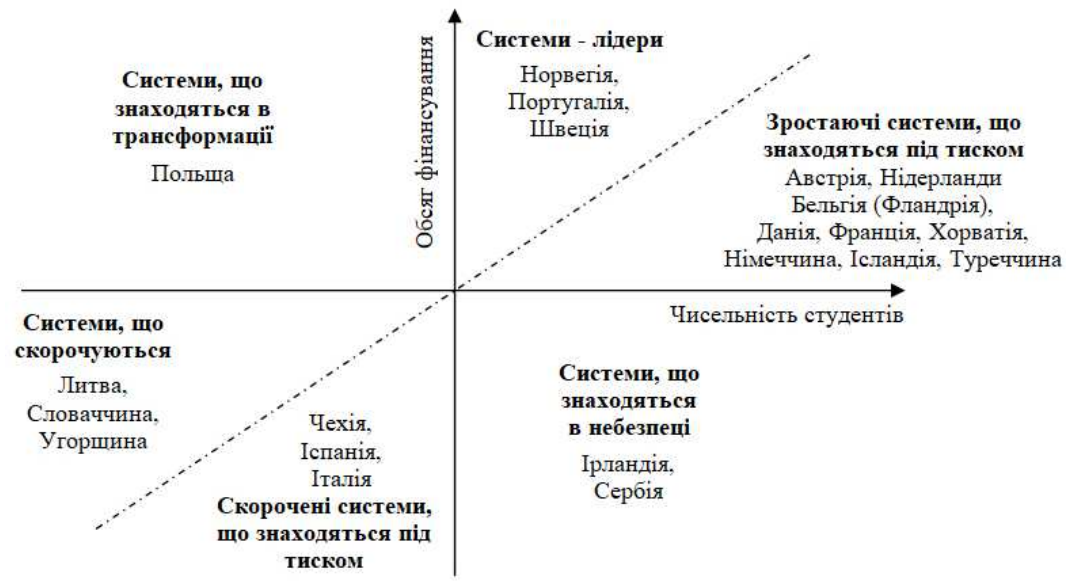

Рис. 2. Моделі освітньої політики країн СС, з огляду на фінансовий та демографічний чинники

Джерело: сформовано автором [15].

Оцінювання освітньої політики у двох координатах фінансування освіти державою та чисельності студентів - дає підстави для виокремлення групи країн-лідерів. Як ілюстровано на рис. 2, до групи лідерів належать Норвегія, Португалія, Швеція. Саме університети цих країн посідають високі місця в міжнародних рейтингах та мають стабільні й достатні, з огляду на зростання кількості студентів, обсяги фінансування. До «зростаючих систем», але таких, що «знаходяться під тиском», бо мають випереджаюче збільшення кількості студентів, належать Австрія, Нідерланди, Фландрія (регіон Бельгії), Данія, Франція, Хорватія, Німеччина, Ісландія, Туреччина. В особливих умовах функціонує освітня система Польщі. Вона ідентифікована як така, що «перебуває в трансформації» та діє при зростаючому державному інвестуванні в університети 3 метою призупинення відтоку молоді 3 навчальних закладів. Усі інші аналізовані країни мають загрожені освітні системи з тенденцією до скорочення.

Важливим складником освітньої політики є оцінювання витрат на освіту. За результатами дослідження під егідою Сврокомісії, з'ясовано важливу закономірність. Виявилося, що ефективність політики, яка оцінювалася за показниками кількості випускників та наукових публікацій, була вищою при більшій автономії університетів [16]. У 
фундаментальному дослідженні, присвяченому державним витратам на освіту в країнах $Є С$ [17], - «Роздуми економістів про інвестиції в людський капітал: наскільки ефективними є державні витрати на освіту в державах-членах СС?» - з'ясовано ще одну цікаву закономірність. Виявлено, що дуже обмежене коло країн ЄС забезпечує ефективність витрат на освіту одночасно за трьома вимірниками. Йшлося про оцінювання: за кількістю здобувачі вищої освіти (I), за якістю освіти за балами PISA (Programme for International Student Assessment) у галузі науки (II), за інклюзивністю, або інверсією молоді в навчальному процесі (III). Деякі країни мали високі результати лише за одними показниками і низькі - за іншими. Близько третини країн демонстрували низькі та спадаючі показники якості освіти, за критерієм PISA. Інформація про оцінювання країн за цим критерієм подана на рис. 3 .

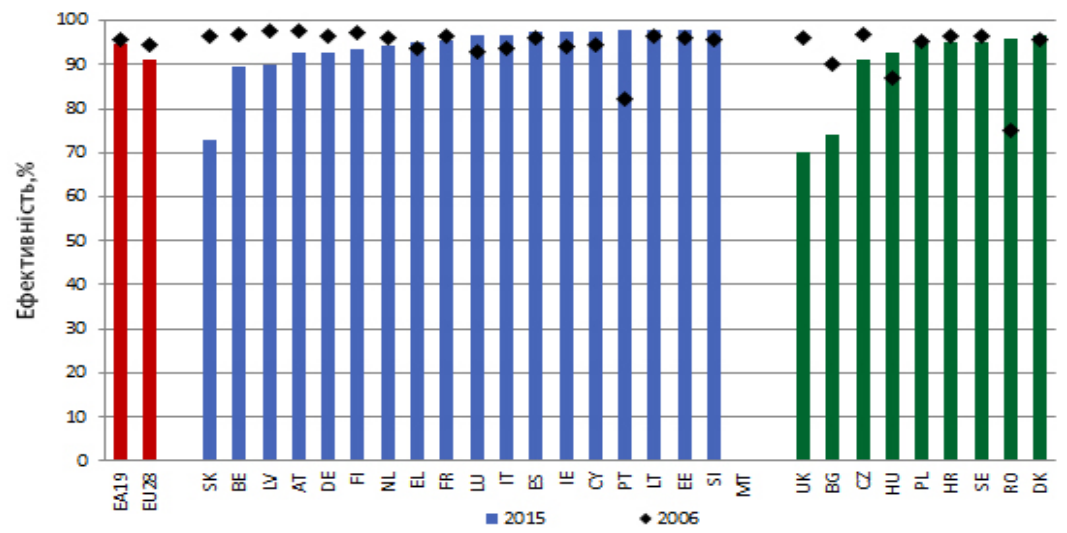

Рис. 3. Оцінка ефективності витрат на освіту, за критерієм PISA Джерело: [18].

Як свідчить ілюстрована на рис. 3 інформація, принаймні десять країн СС у аналізованому періоді демонстрували погіршення показників якості освіти. Показово, що це відбувається у спільноті країн 3 високими показниками добробуту, достатніми можливостями фінансування освіти та інвестиціями в людський капітал.

Для нашого дослідження впливу освіти на економічну невизначеність важливими $є$ такі узагальнення, зроблені при аналізі ефективності витрат на освіту в країнах $\mathrm{CC}$ :

- не існує ідеальної освітньої політики, зокрема через тяглість освітніх традицій і, відповідно, консервативність національних систем освіти; це заважає швидкому пристосуванню до змінюваного середовища;

- удосконалення людського капіталу в Європі відбувається не стільки через збільшення державних витрат на освіту, скільки через 
створення більш досконалих національних моделей використання фінансових ресурсів;

- особи 3 вищим рівнем освіти мають більшу здатність до реагування на загрози безробіття в період економічної невизначеності, натомість, безробіття серед осіб з низьким рівнем освіти в періоди невизначеності та криз суттєво зростає;

- достатнє фінансуванні освіти стає не лише фактором економічної стабільності, впливаючи на економічне зростання, вищу продуктивність та інноваційність, а й фактором соціальної стабільності, впливаючи на зменшення диференціації доходів та на подолання бідності.

Повертаючись до початкової ланки пропонованого нами логічного ланцюжка (рис. 1), через який ми намагалися пояснити вплив освіти на економічну невизначеність, можемо зробити такі узагальнення.

- Освіта, щоб стати інструментом гарантування стабільності, має сприяти найважливішим складникам стійкого розвитку - розумному зростанню (smart growth) та інклюзивному зростанню (inclusive growth). Розумне зростання передбачає, що система освіти забезпечує постійне навчання, оновлення навичок, здатність створювати нові продукти й послуги, використовувати нові джерела інформації та технології. Інклюзивне зростання спирається на те, що система освіти сприяє формуванню навичок спілкування $i$ взаємодї, створенню нових спільнот, участі в управлінні змінами тощо.

Про формування згаданих здатностей та навичок - постійного оновлення знань і взаємодії, участі тощо - йдеться, зокрема, в науковій доповіді про необхідні детермінанти сучасного зростання української економіки [19].

- Освіта покликана формувати иіннісні пріоритети суспільства, без яких жодні успіхи в економічній сфері не гарантуватимуть соціальної єдності та стабільності.

3 огляду на незаперечний факт вирішальної ролі освіти у формуванні цінностей суспільства, заслуговує на увагу ідея української дослідниці про, так званий «ланцюжок результативності освіти» у складі таких ланок: грамотність - освіченість - професійна компетентність - культура - менталітет [20].

- Обмеження економічної невизначеності досягається за рахунок вищого рівня професіоналізації освіти. Професіоналізація, як процес, передбачає здатність людини відповідати постійно змінюваним вимогам до професії. Тому професіоналізм грунтується принаймні на трьох засадах, а саме: 1) на опануванні фундаментальних знань та навичок професії, 2) на перманентному підвищенні кваліфікації, на самовдосконаленні в обраній сфері, 3) на реалізації загальнолюдських та національних цінностей при виконанні професійних функцій. 
Професіоналізація має більш широкий зміст, ніж той, що охоплюється поняттям «професійно-технічна освіта». Останнє в сучасних українських умовах корелює з поняттям так званої «фахової передвищої освіти» [21]. Увага до фахової передвищої освіти була породжена передусім браком на українському ринку праці кваліфікованих представників так званих «робітничих професій». Своєрідною реакцією на незадоволений попит у цьому сегменті ринку праці стала розробка Концепції реалізації державної політики у сфері професійної (професійнотехнічної) освіти «Сучасна професійна (професійно-технічна) освіта» на період до 2027 року [22]. Попри акцентовану увагу української влади до професійно-технічної освіти, проблема професіоналізації освіти, маючи ширший зміст, стала актуальною й для всіх інших сегментів ринку праці.

До ефективних заходів, що забезпечують загальну професіоналізацію освіти, належать такі:

- формування змісту освіти (освітніх програм) на компетентнісній основі - 3 урахуванням того, що повинен уміти, знати, передбачати професіонал, 3 огляду на змінювані обставини професії та потреби споживачів;

- залучення до освітнього процесу успішних професіоналів, професійних об'єднань та роботодавців;

- створення системи професійних кваліфікацій 3 чітким окресленням кола компетентностей фахівців певної професії;

- поєднання різних і найбільш прийнятних для отримувача освіти форм професійної освіти та форм перекваліфікацій.

Перспективними заходами 3 професіоналізації освіти, що носять ознаки інноваційності та апробовані в освітніх системах різних країнах, $€$ такі:

- організація освітнього процесу у формі освітніх кластерів, які поєднують навчальні, наукові заклади та підприємства й організації;

- створення служб супроводу процесу безперервної професійної освіти таких, як, наприклад, адаптаційні, діагностичні, дидактичні, психологічні центри тощо;

- узгодження міжнародних (до прикладу, європейської) рамок кваліфікації з відповідними національними рамками кваліфікації;

- поєднання в освітніх програмах вищих навчальних закладів «навчальних одиниць»- ECTS (European Credit Transfer and accumulation System) 3 «професійними одиницями» - ECVET (European Credit System for Vocational Education and Training);

- створення нових освітніх інституцій - національних центрів, орієнтованих на забезпечення вищого рівня професіоналізму та зайнятості молоді. Наприклад, таких, як італійський центр «Відкриті двері в 
майбутнє» - Porto Futuro, французький центр - Citedes Metries, іспанський центр - Porta 22;

- створення організаційних структур від середньої до вищої, які об'єднують освітні рівні з виробництвом та спрямовують навчання у русло здобуття конкретних кваліфікацій та професій. Наприклад, таких організаційних структур, як кампуси професій і кваліфікацій (Campus des métiers et des qualifications) у Франції, професійні центри компетентності в Латвії.

Зроблені нами узагальнення щодо зв'язку освіти та економічної визначеності $€$ важливими, з огляду на можливість їх застосування в українській економіці. Помічено, що різні складники української економіки демонструють різні рівні економічної визначеності та стабільності. До прикладу, ринок нерухомого майна впродовж усіх років новітньої української економічної історії, починаючи з 1990-х рр., виконував роль своєрідного «амортизатора економіки». Йдеться про нерухоме майно - квартири, споруди, офісні приміщення тощо, - яке завжди було найбільш привабливим активом та об'єктом інвестування для українців. Такі переваги нерухомого майна як активу пояснюються постійним браком альтернативних форм фінансових активів 3 подібним рівнем дохідності, корисності та ризиковості (надійності) вкладень.

Про відносно вищу, ніж у інших сегментах української економіки, стабільність ринку нерухомості свідчить, зокрема, стабільна частка ВВП. На «операції з нерухомим майном» припадає 8-10\% ВВП [23]. На цьому ринку знаходять місця для працевлаштування приблизно 200 тис. українців.

Попри відносно високий «потенціал економічної визначеності», властивий ринку нерухомого майна, він характеризується значною волатильністю. Адже зазвичай він одним з перших реагує на зміни економічної кон'юнктури. Зокрема, так сталося у 2020 р. під час пандемії Covid-19. Ринок нерухомості та ринок туристичних послуг першими відреагували скороченнями продажів на негативні зовнішні впливи та негативні очікування громадян.

Дослідження ринку нерухомого майна на предмет реакції фактичних та потенційних споживачів його послуг засвідчили достатньо високий рівень недовіри. 3'ясовано, що недовіра формується, крім іншого, й через масову відсутність розуміння того, чим займаються та що повинні вміти фахівці цього ринку.

Відсутність більш-менш чітких уявлень про фах, професійні функції операторів на ринку нерухомості властива не лише споживачам послуг. Подібне нерозуміння часто демонструють і національні регулятори цього ринку. Адже в Україні десятиліттями точиться дискусія з приводу того, хто й як має навчати фахівців ринку нерухомості, як має засвідчуватися їх кваліфікація, здійснюватися сертифікація. 
Тобто, освіта фахівців ринку нерухомості є тією «сферою невизначеності», яка перманентно породжує невизначеність на самому ринку. Саме тому актуальним $\epsilon$ вивчення досвіду організації освіти фахівців ринку нерухомості в інших країнах. Не менш важливим $є$ й усвідомлення можливостей застосування такого досвіду для організації подвійної освіти в Україні.

Визначальним орієнтиром для організації освіти фахівців ринку нерухомості може слугувати стандарт «Послуги агентів 3 нерухомості Вимоги до надання послуг агентів 3 нерухомості», затверджений Європейським комітетом з стандартизації, кваліфікації та компетенцій агентів з нерухомості [24].

Перелік професійних компетенцій агентів 3 нерухомості $\epsilon$ принципово важливим для усвідомлення того, якою має бути освіта фахівців цього ринку. Власне перелік охоплює 12 позицій, а саме:

1) розуміння найважливіших фінансових, економічних термінів, пов'язаних з операціями з нерухомістю;

2) обізнаність щодо грошових, кредитних та банківських систем, пов'язаних з сектором нерухомості;

3) інформованість про економічну та політичну ситуації, пов'язані 3 сектором нерухомості;

4) усвідомлення чинників попиту та пропозиції в секторі нерухомості;

5) супровід здійснення інвестицій у нерухомість;

6) маркетинг нерухомості, володіння маркетинговими методами у їх застосуванні для різних видів нерухомості;

7) оцінювання витрат, пов'язаних з використанням нерухомого майна, наприклад, експлуатаційних, спричинених необхідністю страхування тощо;

8) знання принципів та процесів гарантування операцій 3 нерухомістю, а саме: законодавства і практики застосування іпотеки, банківських позик та інших фінансових інструментів;

9) володіння інструментарієм оцінки ринкової вартості нерухомості;

10) здатність здійснити перевірку та вимірювання площ різних типів нерухомості з урахуванням мети вимірювання,

11) обізнаність у царині основ національного та європейського законодавства, нормативів і стандартів, що стосуються підприємництва у сфері нерухомості, оподаткування, охорони праці, екології тощо;

12) здатність складати договори, пов'язані з нерухомістю, або сприяти їх складанню, експертиза існуючих договорів за наслідками певних змін для сторін договору.

Аналіз наведеного переліку компетенцій фахівців ринку нерухомості, за їх змістовим наповненням, дає підстави для виокремлення принаймні чотирьох необхідних складників освіти таких фахівців: 
- економічний компонент (економічна термінологія щодо ринку нерухомості, вплив макроекономічного середовища на ринок, фактори попиту та пропозиції на ринку, інвестування в нерухоме майно, оцінка ринкової вартості нерухомого майна);

- правовий компонент (правові основи гарантування операцій $з$ нерухомістю, застосування норм права у підприємницькій діяльності на ринку нерухомості, укладання та експертиза договорів щодо нерухомого майна);

- фінансовий компонент (володіння фінансовою термінологією щодо ринку нерухомості, обізнаність у царині банківської (кредитної) системи для ринку нерухомості);

- маркетинговий компонент (маркетинговий інструментарій дослідження на ринку нерухомості).

3 огляду на значний обсяг економічних знань, необхідних фахівцеві ринку нерухомості, ми схильні до висновку про доцільність підготовки таких фахівців на основі базової економічної освіти. Зрозуміло, що економічні знання мають органічно поєднуватися з трьома іншими елементами освітнього процесу. Йдеться про правовий, фінансовий та маркетинговий компоненти у застосуванні саме до ринку нерухомості.

Далі подано десять прикладів 3 досвіду реалізації освітніх програм, пов'язаних з підготовкою фахівців для ринку нерухомості, в розвинених країнах зі сформованим та інституціоналізованим ринком (аналітична табл. 2).

Таблиия 2

Освітні заклади та програми підготовки фахівців для ринку нерухомості

\begin{tabular}{|l|l|l|}
\hline \multicolumn{1}{|c|}{ Освітні заклади } & $\begin{array}{l}\text { Партнери, долучені до } \\
\text { освіти фахівців, та/або } \\
\text { професійні спільноти, } \\
\text { що здійснюють освітню } \\
\text { діяльність }\end{array}$ & \multicolumn{1}{|c|}{ Зміст освітньої програми } \\
\hline $\begin{array}{l}\text { Флоридський } \\
\text { міжнародний університет } \\
\text { (Маямі, США) }\end{array}$ & $\begin{array}{l}\text { Школа нерухомості Hollo } \\
\text { та Вища школа бізнесу } \\
\text { Алва Х. Чепмена }\end{array}$ & $\begin{array}{l}\text { Програма навчання 3 } \\
\text { міжнародного управління } \\
\text { нерухомістю }\end{array}$ \\
\hline $\begin{array}{l}\text { Баухауз-Університет } \\
\text { Веймару (Веймар, } \\
\text { Німеччина) }\end{array}$ & $\begin{array}{l}\text { Бакалаврські та магістерські } \\
\text { програми з менеджменту зі } \\
\text { спеціалізацією у сфері } \\
\text { нерухомості й майстер-класами } \\
\text { практикуючих фахівців ринку }\end{array}$ \\
\hline $\begin{array}{l}\text { Антверпенська школа } \\
\text { менеджменту } \\
\text { (Антверпен, Бельгія) }\end{array}$ & $\begin{array}{l}\text { Сдина в країні магістерська } \\
\text { програма з нерухомості, яка дає } \\
\text { можливість отримати диплом } \\
\text { магістра з нерухомості (МRЕ) з } \\
\text { відповідними тренінгами }\end{array}$ \\
\hline
\end{tabular}


Продовження табл. 2

\begin{tabular}{|c|c|c|}
\hline $\begin{array}{l}\text { Kogod School of Business } \\
\text { (Вашингтон, США) }\end{array}$ & $\begin{array}{l}\text { Професійні асоціації } \\
\text { нерухомості США }\end{array}$ & $\begin{array}{l}\text { Магістерська програма з } \\
\text { нерухомості зі спеціалізацією: } \\
\text { комерційний розвиток та } \\
\text { інвестиційний банкінг, іпотечне } \\
\text { фінансування }\end{array}$ \\
\hline $\begin{array}{l}\text { Массачусетський } \\
\text { технологічний інститут } \\
\text { (США) }\end{array}$ & $\begin{array}{l}\text { Центр нерухомості (1983 } \\
\text { р. заснування), створений } \\
\text { відомим американським } \\
\text { девелопером, } \\
\text { випускником } \\
\text { Массачусетського } \\
\text { технологічного інституту } \\
\text { Ч. Сполдингом }\end{array}$ & $\begin{array}{l}\text { Магістерська програма з розвитку } \\
\text { нерухомості, що охоплює курси } \\
\text { «Фінанси та розвиток } \\
\text { нерухомості», «Економіка } \\
\text { нерухомості», «Стратегічний } \\
\text { розвиток нерухомості», «Складні } \\
\text { міські проєкти», «Ризики } \\
\text { нерухомості», «Лідерство у } \\
\text { сфері нерухомості» тощо }\end{array}$ \\
\hline $\begin{array}{l}\text { Неаполіський університет } \\
\text { у Пафосі (Кіпр) }\end{array}$ & $\begin{array}{l}\text { Королівський інститут } \\
\text { дипломованих геодезистів } \\
\text { у регіоні Східного } \\
\text { Середземномор'я } \\
\end{array}$ & \begin{tabular}{|l|} 
Перша спеціальна програма 3 \\
нерухомості для Кіпру та Греції
\end{tabular} \\
\hline $\begin{array}{l}\text { Гронінгенський } \\
\text { університет (Гронінген, } \\
\text { Нідерланди) }\end{array}$ & $\begin{array}{l}\text { Королівський інститут } \\
\text { дипломованих геодезистів }\end{array}$ & $\begin{array}{l}\text { Міждисциплінарна магістерська } \\
\text { програма в галузі нерухомості, } \\
\text { побудована у співпраці } \\
\text { факультетів просторових наук, } \\
\text { економіки та права } \\
\end{array}$ \\
\hline $\begin{array}{l}\text { Люцернський університет } \\
\text { прикладних наук і } \\
\text { мистецтв (Люцерн, } \\
\text { Швейцарія) }\end{array}$ & & $\begin{array}{l}\text { Навчальна програма зі } \\
\text { спеціалізацією: ринки } \\
\text { нерухомості та інвестиції в } \\
\text { нерухомість з тренінгами від } \\
\text { фахівців ринку } \\
\end{array}$ \\
\hline $\begin{array}{l}\text { Кембридж (Велика } \\
\text { Британія) }\end{array}$ & & $\begin{array}{l}\text { Програма «Оцінка ринків } \\
\text { нерухомості» як самостійна та як } \\
\text { навчальний курс } 3 \text { такою ж } \\
\text { назвою в інших програмах } 3 \\
\text { тренінгами від фахівців } \\
\end{array}$ \\
\hline $\begin{array}{l}\text { Школа архітектури та } \\
\text { дизайну в складі IE } \\
\text { University (Іспанія) }\end{array}$ & & $\begin{array}{l}\text { Магістерська програма з } \\
\text { підготовки фахівців з розвитку } \\
\text { нерухомості зі спеціалізацією у } \\
\text { сфері інвестицій у міську } \\
\text { інфраструктуру з відповідними } \\
\text { тренінгами }\end{array}$ \\
\hline
\end{tabular}

Джерело: створено авторами самостійно на основі інформації, поданої на сайтах відповідних освітніх закладів.

Узагальнюючи досвід освіти фахівців ринку нерухомості, спираючись на наведені приклади, можна фіксувати таке:

1. Існують різні моделі освіти фахівців ринку нерухомості, а саме:

a) на магістерському (переважаюча модель) та на бакалаврському рівнях;

б) у межах інших, більш широких напрямків підготовки (менеджерського, економічної аналітики, фінансового тощо рівнів) та 
власне в межах спеціального напрямку - фахівців ринку нерухомості 3 отриманням диплому магістра нерухомості.

2. Заклади вищої освіти можуть забезпечувати професійну підготовку, в різний спосіб будуючи свої взаємини з практиками ринку нерухомості: а) координуючи свою діяльність 3 професійними громадськими об'єднаннями, б) залучаючи окремих успішних фахівців та аналітиків ринку до освітнього процесу.

3. Попри відмінності у моделях та способах підготовки фахівців для ринку нерухомості, вона здійснюється у вищих навчальних закладах (університетах) різних країн. Отже, передбачається, що цей фах спирається на широкі (універсальні) знання і певний світогляд, а не лише на вузькі функції та просте механічне відтворення певних дій.

4. Освіта фахівців ринку нерухомості має багато спеціалізацій, включно з тими, які пов'язані з новими процесами у містобудуванні, у вирішенні екологічних проблем тощо. Тому освітніми програмами передбачено різні - змінювані під актуальні потреби суспільства акценти у підготовці фахівців ринку нерухомості.

Український ринок нерухомості не можна вважати ні розвиненим, ні остаточно сформованим через неврегульованість процедур та процесів. Ідеться передусім про процеси надання професійної освіти, здійснення сертифікації фахівців тощо.

Попри остаточну несформованість ринку нерухомості, на ньому вже виокремилися принаймні чотири професії, що дістали визнання в українському суспільстві: оцінювачі майна, агенти з нерухомого майна (рієлтори), управляючі нерухомістю (включно 3 управляючими багатоквартирними будинками), дівелопери.

Для згаданих професій сформувалася певна система підготовки фахівців. Аналіз цих систем дає можливість окреслити основні проблеми освіти фахівців українського ринку нерухомості. Інформацію про фактичний стан освіти фахівців ринку нерухомості подано в аналітичних табл. 3-6.

За інформацією, поданою в аналітичній табл. 3, підготовка фахівців ринку нерухомості у сегменті оцінювачів майна здійснюється органом державної влади - Фондом державного майна - та згідно 3 чинним Законом України. Це надає такій підготовці достатньо високого рівня легітимності. Зміст програм, на які ми посилаємося, на наш погляд, звужує роль оцінювачів майна. Адже в програмах найбільше акцентується увага на «оцінці для цілей оподаткування». Натомість, оцінка майна має значно ширше коло економічних, фінансових, соціальних наслідків, ніж просто сприяння збільшенню податкових надходжень до бюджету. 
Таблиия 3

Українська професійна освіта в оціночній діяльності

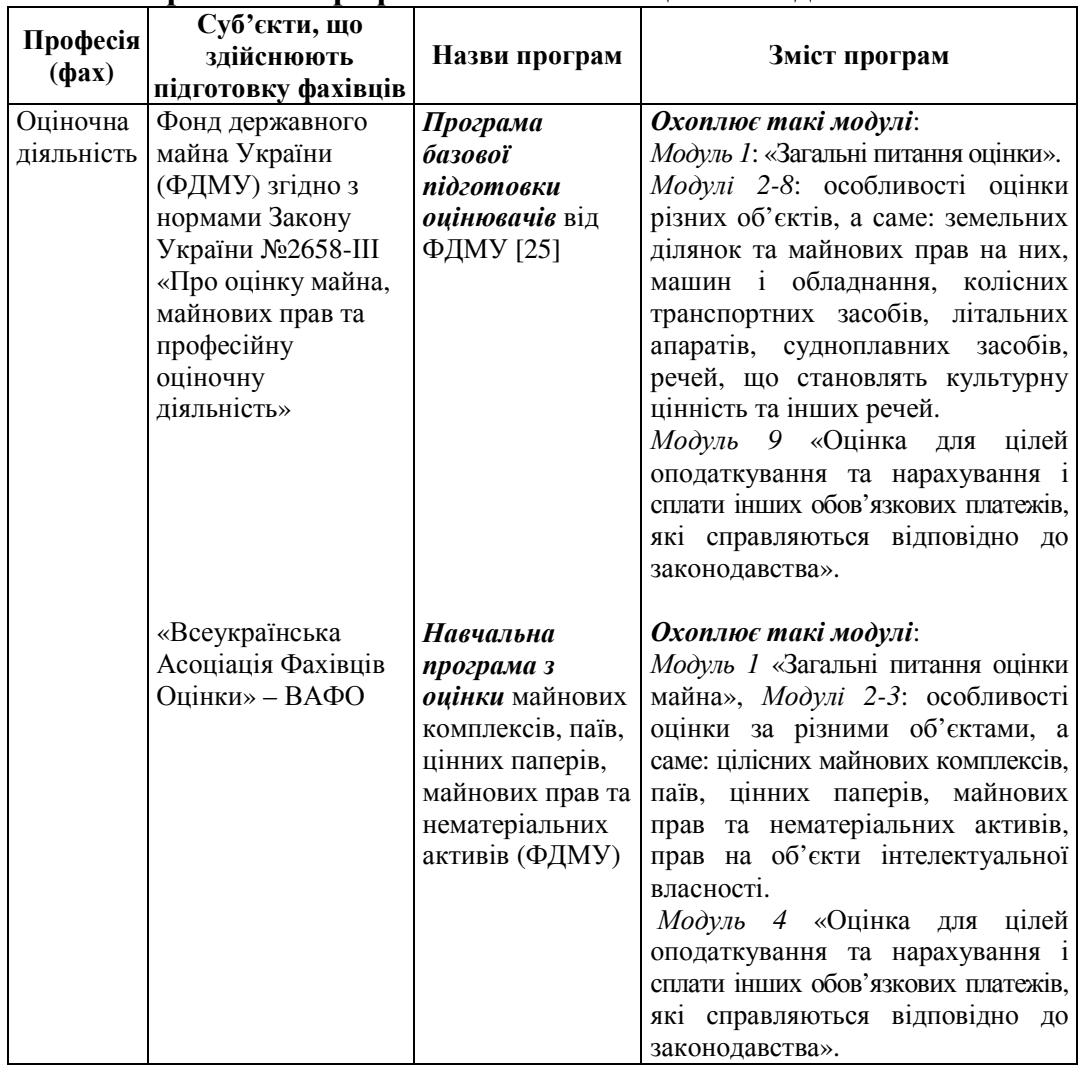

Джерело: створено авторами самостійно.

Таблиия 4

Українська професійна освіта в діяльності агентів нерухомості (ріслторів)

\begin{tabular}{|c|c|c|c|}
\hline $\begin{array}{c}\text { Професія } \\
\text { (фах) }\end{array}$ & $\begin{array}{c}\text { Суб'скти, що } \\
\text { здійснюють } \\
\text { підготовку } \\
\text { фахівців }\end{array}$ & $\begin{array}{c}\text { Назви } \\
\text { програм }\end{array}$ & Зміст програм \\
\hline $\begin{array}{l}\text { Агент } 3 \\
\text { нерухомого } \\
\text { майна } \\
\text { (рієлтор) } 3 \\
\text { елементами } \\
\text { підготовки } \\
\text { керуючого } \\
\text { нерухомістю }\end{array}$ & $\begin{array}{l}\text { Громадська } \\
\text { організація } \\
\text { «Асоціація } \\
\text { фахівців } \\
\text { нерухомості } \\
\text { (рієлторів) } \\
\text { України» - } \\
\text { АФНРУ в } \\
\end{array}$ & \begin{tabular}{|l|} 
Цикл \\
навчальних \\
курсів СРМ \\
(Ступінь \\
Certified \\
Property \\
Manager - \\
Сертифікований \\
\end{tabular} & $\begin{array}{l}\text { Oхоплює такі теми: } \\
\text { «Обслуговування власності та } \\
\text { управління ризиками», «Основи } \\
\text { управління людськими ресурсами для } \\
\text { керуючих нерухомістю», «Маркетинг і } \\
\text { оренда: нерухомість для роздрібної } \\
\text { торгівлі», «Маркетинг і оренда: } \\
\text { багатоквартирна нерухомість», }\end{array}$ \\
\hline
\end{tabular}


Продовження табл. 4

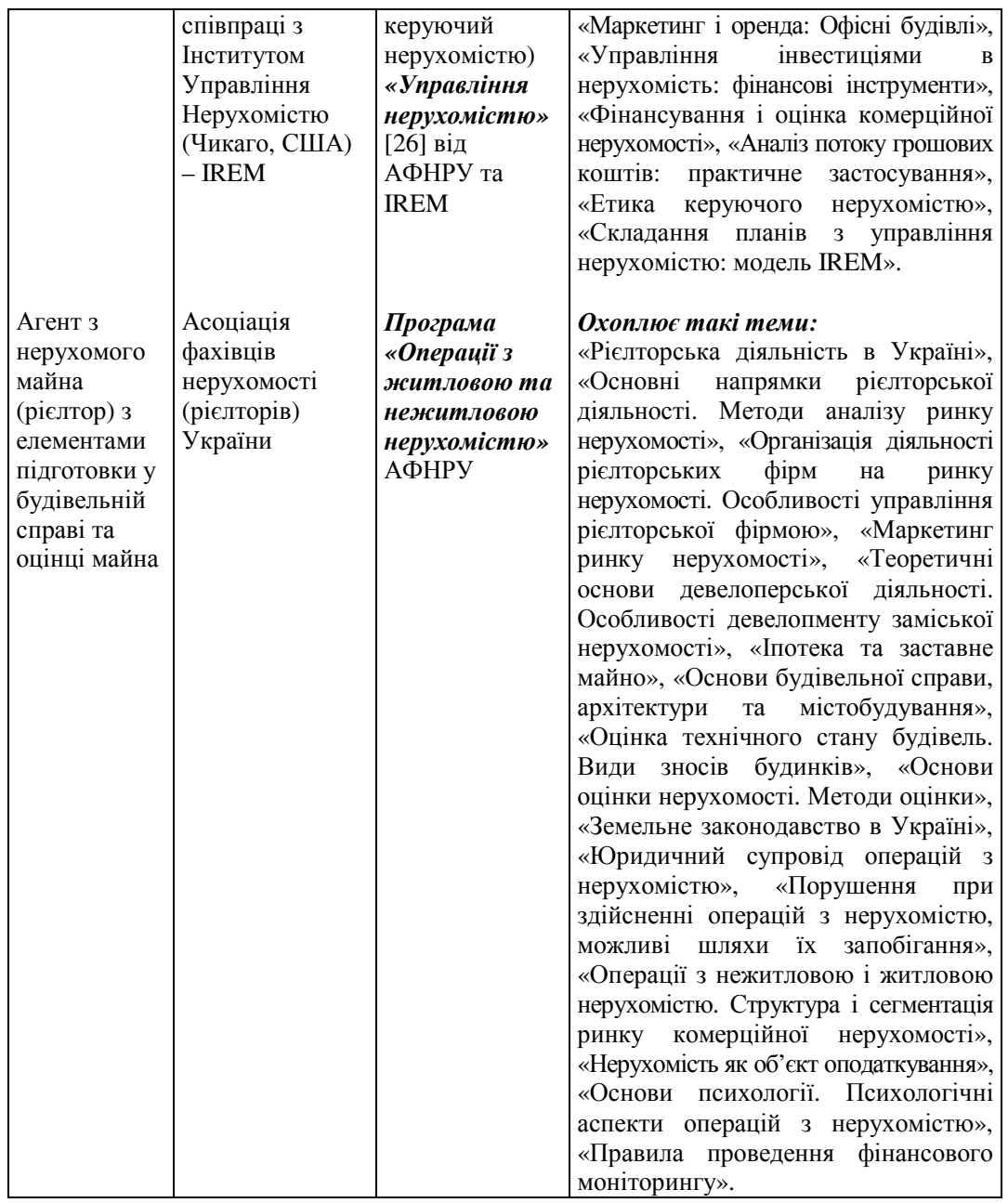

Джерело: створено авторами самостійно.

Аналіз інформації, поданої в аналітичній табл. 4, дає підстави для таких узагальнень щодо чинної системи професійної підготовки агентів нерухомості (рієлторів):

- дві чинні пропоновані програми, передбачаючи широке коло компетенцій, є подібними до програм університетів інших країн. Це надає їм незаперечні переваги. Але ці програми передбачають нетривалу в часі підготовку фахівців. Тому, ймовірно, в повному обсязі вони 
можуть бути засвоєні лише особами, які вже мають економічні, маркетингові, фінансові, правові, психологічні тощо знання та практичні навички. Саме такі знання й навички передбачено університетською освітою;

- зміст аналізованих програм не свідчить про чіткі уявлення щодо кваліфікації (так званої «кваліфікаційної рамки») агента 3 нерухомості (рієлтора). Такий висновок випливає, на наш погляд, принаймні з того, що програма «заводить» цей фах у сферу будівельної справи.

Таблиия 5

Українська професійна освіта в управлінні нерухомістю

\begin{tabular}{|c|c|c|c|}
\hline $\begin{array}{c}\text { Професія } \\
\text { (фах) }\end{array}$ & $\begin{array}{c}\text { Суб'єкти, що } \\
\text { здійснюють } \\
\text { підготовку } \\
\text { фахівців }\end{array}$ & $\begin{array}{c}\text { Назви } \\
\text { програм }\end{array}$ & Зміст програм \\
\hline $\begin{array}{l}\text { Управляючий } \\
\text { на ринку } \\
\text { нерухомості }\end{array}$ & \begin{tabular}{|l} 
Київський \\
національний \\
торговельно- \\
економічний \\
університет - \\
КНТЕУ
\end{tabular} & \begin{tabular}{|l} 
Професійна \\
програма \\
підвицення \\
кваліфікації \\
менеджерів \\
ринку \\
нерухомості \\
КНТЕУ
\end{tabular} & $\begin{array}{l}\text { Oхоплює такі теми: } \\
\text { «Аналіз структури ринку нерухомості», } \\
\text { «Введення в девелопмент, в архітектуру } \\
\text { та містобудування», «Правові аспекти } \\
\text { діяльності на ринку нерухомості, види } \\
\text { договорів», «Основи фінансового та } \\
\text { інвестиційного менеджменту на ринку } \\
\text { нерухомості», «Основи оціночної } \\
\text { діяльності та управління дохідною } \\
\text { нерухомістю», «Практика роботи на } \\
\text { ринку послуг з нерухомості та кодекс } \\
\text { етики фахівців з нерухомого майна», } \\
\text { «Просування послуг на ринку } \\
\text { нерухомості, основи побудови баз } \\
\text { даних та інформаційне забезпечення } \\
\text { діяльності фірм з нерухомості», } \\
\text { «Формування психологічної готовності } \\
\text { рієлтора до успішної професійної } \\
\text { діяльності та психологія конфліктів». }\end{array}$ \\
\hline
\end{tabular}

Джерело: створено авторами самостійно.

Подана в табл. 5 інформація свідчить про те, що український вищий навчальний заклад КНТЕУ пропонує не систему освіти фахівців ринку нерухомості, а систему їх перепідготовки. Відтак, передбачається, що відповідна освіта та практичний досвід уже попередньо отримані. Тому існування такої програми не вирішує питання про власне систему освіти «управляючих на ринку нерухомості».

Власне факт існування навчальної програми, презентованої у табл. 6, та факт сертифікації менеджерів (управителів) багатоквартирними будинками $\epsilon$ адекватною реакцією професійної спільноти в особі ЕМАУ. Це відповідь на формування нового сегменту ринку нерухомості й нових, раніше не задоволених потреб споживачів. У зв'язку 3 
аналізованою програмою, як і в зв'язку з іншими програмами, виникає обгрунтований сумнів. Він стосується того, чи може бути повноцінною підготовка у стислі терміни, якщо учасники програми не мають необхідних знань у царині права, економіки, управління тощо.

Таблиця 6

Українська професійна освіта в управлінні нерухомістю в частині багатоквартирних будинків

\begin{tabular}{|c|c|c|c|}
\hline $\begin{array}{c}\text { Професія } \\
\text { (фах) }\end{array}$ & $\begin{array}{c}\text { Суб'скти, що } \\
\text { здійснюють } \\
\text { підготовку } \\
\text { фахівців } \\
\end{array}$ & Назви програм & Зміст програм \\
\hline $\begin{array}{l}\text { Менеджери } \\
\text { (управителі) } \\
\text { багатоквар- } \\
\text { тирними } \\
\text { будинками }\end{array}$ & $\begin{array}{l}\text { Громадська } \\
\text { спілка } \\
\text { «Експертна } \\
\text { Міжгалузева } \\
\text { Асоціація } \\
\text { України» - } \\
\text { ЕМАУ }\end{array}$ & \begin{tabular}{|l|} 
Програма підготовки \\
менеджерів \\
(управителів) \\
багатоквартирного \\
будинку (групи \\
будинків) та/або \\
керівного складу \\
підприємства \\
житлово-комунального \\
господарства (ЖКГ) \\
від ЕМАУ \\
\end{tabular} & $\begin{array}{l}\text { Oxоплюс такі модулі: } \\
\text { «Організаційно-правові та економічні } \\
\text { аспекти діяльності з управління та } \\
\text { утримання житлового комплексу», } \\
\text { «Техніко-технологічні аспекти } \\
\text { безпечної експлуатації та утримання } \\
\text { житлового комплексу», «Сучасні } \\
\text { стандарти менеджменту та програмні } \\
\text { засоби з управління та утримання } \\
\text { житлового комплексу». }\end{array}$ \\
\hline
\end{tabular}

Джерело: створено авторами самостійно.

Загальні висновки з аналізу української освіти фахівців ринку нерухомості, на наш погляд, можуть бути такими:

- чинна фрагментарна освіта фахівців не $\epsilon$ системою, легітимізованою на основі релевантного законодавства та узгодження з професійними спільнотами вимог до кваліфікації;

- лакуни існуючої системи освіти фахівців ринку активно компенсуються діяльністю громадських організацій - ВАФО, АФНРУ, ЕМАУ, - які зацікавлені в професіоналізмі всіх операторів ринку та членів згаданих асоціацій;

- освіта, пропонована за ініціативою професійних асоціацій, має низку обмежень, пов'язаних з термінами, викладацькими кадрами, джерелами додаткових витрат тощо, тому не може бути цілком покладена на ці асоціації;

- освіту фахівців ринку доцільно здійснювати в поєднанні зусиль університетів, що надаватимуть базову освіту, та професійних асоціацій, які, співпрацюючи 3 університетами в наданні базової освіти, організовуватимуть професійну сертифікацію, визнання кваліфікації та перекваліфікацію;

- органи державної влади (комісії, комітети, фонди тощо) можуть бути учасниками системи освіти фахівців ринку в ролі так званих «третіх осіб», не претендуючи на роль «перших осіб» в освітньому процесі. 
Одна 3 можливих моделей освіти потенційних фахівців ринку нерухомості реалізується в Університеті «КРОК» на кафедрі теоретичної та прикладної економіки (КТПЕ). Ця модель грунтується на таких засадах:

- імплементації в освітні програми бакалаврського рівня двох спеціальностей - 051 «Економіка» та 076 «Підприємництво, торгівля та біржова діяльність» - дисциплін за вибором студентів, що стосуються економіки нерухомості, оцінки нерухомості та підприємництва на ринку нерухомості;

- узгодження переліку та змісту пропонованих кафедрою дисциплін за вибором студентів 3 професійними асоціаціями фахівців ринку нерухомості, а саме: з АФРНУ та ЕМАУ;

- залучення до освітнього процесу викладачів, які мають досвід роботи в якості професійних оцінювачів, рієлторів, управляючих нерухомістю, власників рієлторських, оціночних тощо агенцій;

- створення при кафедрі ТПЕ Лабораторії управління капіталом та майном, до функцій якої належить організація мінітренінгів та семінарів від провідних фахівців ринку нерухомості.

\section{Висновки:}

Дослідження зв'язку між освітою та економічною визначеністю дає підстави для таких узагальнень:

- освіта сприяє досягненню вищого рівня економічної визначеності тоді, коли іiі заміст та форми забезпечують нагромадження людського капіталу за вимогами сталого розвитку. Останній передбачає реагування на технічні інновації та адаптивність і залученість (інклюзію) громадян до життя суспільства;

- вплив освіти на формування людського капіталу, зазвичай, опосередкований освітньою політикою. В іiі межах обираються інструменти й правила, включно з тими, що стосуються державного фінансування освіти. Критеріями успішності освітньої політики та ефективності витрат держави на освіту має бути не лише зростання кількості осіб, охоплених освітою, а й досягнення показників якості освіти за визнаними суспільством стандартами;

- вищий рівень економічної визначеності пов'язаний 3 професіоналізацією освіти - процесом, який означає формування здатності відповідати змінюваним вимогам до професії. Така відповідність досягається при поєднанні неперервної освіти та професійної діяльності з участю у професійних спільнотах тощо;

- одним із сегментів української економіки, досягнення стабільності в якому суттєво залежить від формування системи освіти та сертифікації спеціалістів, є ринок нерухомості. Професіоналізація освіти фахівців цього ринку передбачає упорядкування національної кваліфікаційної 
рамки, обрання релевантної моделі освіти й моделі визнання кваліфікації та іiі офіційне визнання. Перспективною моделлю професіоналізації освіти для ринку нерухомості $є$ поєднання університетської економічної освіти 3 іншими елементами. Йдеться про поєднання 3 орієнтованою на потреби ринку нерухомості фінансовою, правовою, маркетинговою освітою. Ще більш впливовими учасниками, замовниками змісту освіти та оцінювачами ії якості мають ставати громадські професійні асоціації фахівців ринку нерухомості.

\section{Лimepamypa:}

1. Sustainable Development. OECD. 2011. URL : https://www.oecd.org/ greengrowth/47445613.pdf.

2. Promote inclusive and sustainable economic growth, employment and decent work for all. URL : https://www.un.org/sustainabledevelopment/ economicgrowth.

3. Бобух I. М., Щегель С. М. Стратегічні орієнтири економічного зростання України: інклюзивність як ключовий пріоритет. Вісник Національної академії наук Украӥни. 2018. №7. С. 55-70.

4. Перетворення нашого світу: Порядок денний у сфері сталого розвитку до 2030 року. ПРООН в Україні. URL : http://www.ua.undp.org/ content/ukraine/uk/home/library/sustai/nable/developmentreport/the2030ag endaforsustainabledevelopment.html.

5. Долан Э. Дж., Линдсей Д. Е. Рынок: микроэкономическая модель. СПб., 1992.

6. Center for Global Development. «Education and The Developing World». 2014. URL : https://www.cgdev.org/ publication/educationanddeve lopingworld.

7. Smith J. P., Welch, F. R. Closing the gap: Forty years of economic progress for Blacks. (R3330DOL). Santa Monica: The Rand Corporation. 1986.

8. Шульга Н. Д. Основні напрями вдосконалення державної освітньої політики як інструмента соціально-економічного розвитку країни. Вісник післядипломної освіти. Серія : Управління та адміністрування. 2017. Вип. 3. С. 138-150. URL: http://nbuv.gov.ua/ UJRN/vpoupra_2017_3_13.

9. The role of education in the sustainable development agenda. Empowering a learning society for sustainability through quality education. URL : https://www.google.com/url? sa=t\&rct=j\&q=\&esrc/=s\&source=web $\& c d=4 \& v e d=0$ ahUKEwiGmurYkMbaAhWQbFAKHacQDlkQFghIMAM \& url=https3A2F2Fpub.iges.or.jp2Fpub_file2F05ch5achievingthesdgspdf2Fdo wnload\&usg=AOvVaw1CYZk9Uqf0oQ8NScDavd2C.

10. The Human Capital Project. 2018. URL : https://openknowledge. worldbank.org/handle/10986/30498. 
11. Корсак К. В. Освіта, суспільство, людина в XXI столітті: інтегрально-філософський аналіз. Київ-Ніжин, 2004. 210 с.

12. Шульга Н. Д. Державна освітня політика як інструмент соціально-економічного розвитку України: теоретико-методологічний аналіз : монографія. Київ : НТУ, 2016. 355 с.

13. Economic Governance - Guidelines for Effective Financial Management (Paperback). United Nations. New York, 2000. URL : https://publicadministration.un.org/publications/content/PDFs/ELibrary20 Archives/200020Economic20Governance_Guidelines/20for20Effective20 Financial20Management.pdf.

14. Pruvot Enora Bennetot, Estermann Thomas, Lisi Valentina. Public Funding Observatory Report. 2018. URL : https://eua.eu/downloads/ publications/eua20pfo20201820report_1420march202019_final.pdf.

15. Enora Bennetot Pruvot, Thomas Estermann, Veronika Kupriyanova. Public Funding Observatory. Report 2019/2020. URL : https://www.eua.eu/ resources/publications/913:eua-public-funding-observatory-report-2019-20.html.

16. Pruvot Enora Bennetot, Estermann Thomas, Lisi Valentina. Public Funding Observatory Report. 2018. URL : https://eua.eu/downloads/ publications/eua20pfo20201820report_1420march202019_final.pdf.

17. St. Aubyn, M., Garcia, F., \& Pais, J. Study on the efficiency and effectiveness of public spending on tertiary education. Directorate General Economic and Financial Affairs (DG ECFIN), European Commission. 2009. №390.

18. Economists' Musings on Human Capital Investment: How Efficient is Public Spending on Education in EU Member States? European Commission. URL : https://ec.europa.eu/info/publications/economy-finance/ economists-musings-human-capital-investment-how-efficient-publicspending-education-eu-member-states_en.

19. Національні та глобальні детермінанти економічного зростання України: наукова доповідь / за ред. I. М. Бобух. Київ, 2018. 390 с. URL : http://ief.org.ua/docs/sr/299.pdf.

20. Новосад О. В. Освіта як вища цінність людини і суспільства. Управління в освіті. V Міжнародної науково-практичної конференції, 14-16 квітня 2011 року : збірник матеріалів. Львів : Видавництво Львівської політехніки, 2011. С. 225-227.

21. Про фахову передвищу освіту : Закон України від 06.06.2019 №2745-VIII. URL : https://zakon.rada.gov.ua/laws/show/2745-19.

22. Про схвалення Концепції реалізації державної політики у сфері професійної (професійно-технічної) освіти «Сучасна професійна (професійно-технічна) освіта» на період до 2027 року : Розпорядження КМУ від 12 червня 2019 р. №419-p. URL: https://www.kmu.gov.ua/npas/ pro-shvalennya-koncepciyi-realizaciyi-derzhavnoyi-politiki-u-sferiprofesijnoyi-profesijno-tehnichnoyi-osviti-suchasna-profesijna-profesijnotehnichna-osvita-na-period-do-2027-roku-i120619. 
23. Dunia Pepe, Piera Casentini Innovation in VET: Italy. CEDEFOP. ReferNet. URL : https://cumulus.cedefop.europa.eu/files/vetelib/2014/2014 _Innovation_in_VET_IT.pdf.

24. Services of real estate agents - Requirements for the provision of services of real estate agents. URL : https://www.en-standard.eu/csn-en15733-services-of-real-estate-agents-requirements-for-the-provision-ofservices-of-real-estate-agents/.

25. Офіційний сайт Фонду Державного майна України. URL : http://www.spfu.gov.ua/ua/content/spf-estimate-trainings-basic.html.

26. Офіційний сайт Асоціації спеціалістів 3 нерухомості (рієлторів) України. URL : http://www.asnu.net/. 